\title{
PKM SD GMIM 54 LAPANGAN
}

\author{
Paula Audry Rombepajung \\ Universitas Negeri Manado \\ paularombepajung@unima.ac.id
}

\begin{abstract}
Abstrak
SD GMIM 54 Lapangan meupakan salah satu dati sekian banyak sekolah dasar yang ada di kota Manado. Pemerintah Kota Manado melalui Dinas Pendidikan terus berupaya meningkatkan mutu Pendidikan dengan berbagai program. Walaupun demikian masih banyak yang dibutuhkan oleh pihak sekolah baik dilihat dari tim pengajar, peserta didik dan beberapa hal yang menunjang kegiatan belajar mengajar. Pengabdian Masyarakat ini bertujuan memberikan pelatihan bahasa Inggris melalui media visual sebagai media pembelajaran kedapa siswa SD GMIM 54 Lapangan. Target dan luaran yang dihasilkan dari kegiatan ini yaitu : Adanya minat dan daya tarik dalam mempelajari bahasa Inggris karena materi dan penyampaiannya menggunakan konsep belajar sambil bermain sehingga kegiatan belajar menjafi aktif dan para siswa tidak bosan dan tidak menjadi satu beban dalam mempelajari materi yang disampaikan. Luaran yang diharapkan mealui PKM didanai melaui Dana DIPA UNIMA adalah dalam DIPA Program Kemitraan Masyarakat yang didanai oleh UNIMA adapun luaran yang dihasilkan dalam bentuk Artikel atau Jurnal :PKM SD GMIM 54 Lapangan. Oleh karena itu diharapkan agar kegiatan seperti ini kembali dapat dilaksanakan untuk meningkatkan kemampuan ketrampilan berbahasa para sisw-siswa SD setelah memperoleh ketrampilan dasar ini
\end{abstract}




\section{PENDAHULUAN}

SD GMIM 54 Lapangan meupakan salah satu dati sekian banyak sekolah dasar yang ada di kota Manado. Pemerintah Kota Manado melalui Dinas Pendidikan terus berupaya meningkatkan mutu Pendidikan dengan berbagai program. Walaupun demikian masih banyak yang dibutuhkan oleh pihak sekolah baik dilihat dari tim pengajar, peserta didik dan beberapa hal yang menunjang kegiatan belajar mengajar.

Siswa merupakan unsur penting dalam rangkaian kegiatan pembelajaran. Siswa akan secara langsung mendapatkan perlakuan dari pengajar dan merasakan proses pembelajaran yang dilakukan oleh guru. Banyak sekali media pembelajaran yang digunakan, namun dalam pelatihan inidigunakan media visual gambar yang lebih efektif untuk para siswa SD.

Program pelatihan bahasa Inggris menggunakan media visual gambar sebagai media pembelajaran sangat penting guna memperlancar pembelajaran menjadi menyenangkan dan mudah dimengerti oleh siswa. Media pembelajaran dipergunakan untuk mempermudah dalam penyampaian materi kepada siswa. Pemanfaatan media visual juga berperan besar dalam memberikan pengalaman belajar para siswa. Media visual ini berperan besar dalam mengkomunikasikan pesan yang disampaikan oleh guru. Metode pembelajaran dan media pembelajaran akan menentukan kualitas suatu proses pembelajaran. Penggunaan media visual dalam proses pembelajaran sejalan dengan pandangan (Dwyer;1997) salah seorang tokoh aliran realism yang menwgaskan bahwa belajar yang sempurna hanya dapat dicapai jika menggunakan bahan-bahan yang visual yang mendekati realitas. Hal ini sejalan dengan pandangan dari Milar,dkk,1957 yang mengatakan bahwa makin banyak sifat bahan media visual yang menyerupai realitas, maka semakin mudah pula terjadinya proses belajar pada diri siswa. Pada prakteknya penggunaan media visual gambar, lebih banyak digunakan pada anak-anak berusia 7-13 tahun atau pada anak-anak sekolah dasar dibandingkan pana anak anak sekolah menengah keatas, sebab pada anak-anak ini belum mampu berpikir abstrak. Sehingga materi yang diberikan perlu divisualisasikan dalam bentuk yang nyata. Dengan cara seperti itu dapat membantu anak-anak dalam proses internalisasi berbagai pengetahuan yang diajarkan oleh guru dalam proses pembelajaran.

\section{Permasalahan Mitra}

Permasalahan utama yang dihadapi oleh mitra adalah mata pelajaran bahasa inggris yang hanya diterapkan sebagai Matapelajaran tambahan. Di SD GMIM 54 Lapanganini, bahasa inggris tidak diajarkan seperti pada Sekolah Dasar lain. SD GMIM 54 Lapangan belum menerapkan adanya pembelajaran bahasa Inggris, yang pada dasarnya sudah menjadi bahasa 
Internasional. Disekolah ini, selsi bahada Indonesia yang wajib diajarkan, mereka pun diajarkan bahasa daerah yang dikensl dengan Muatan Lokal (Mulok). Berdasarkan informasi yang ada sebenarnya bahasa Inggris bisa dijadikan sebagsi Mata pelajaran, namun karena keterbatasan media pembelajaran, kurangnya ketertarikan akan bahasa Inggris sehingga sampai saat ini belum terealisasikan. Sentuhan teknologi yang masih sangat kurang membuat guru dan sekolah kurang kreatif dalam merancang kegiatan pembelajaran atau proses belajar mengajar masih trafisional. Kurangnya kemampuan guru dalam memvisualisasikan materi maka akan berdampak pada rendahnya kemampuan analisis dan kemampuan siswa.

Oleh sebab itu pelaksana membantu untuk memperkenalkan bahasa Inggris melalui proses pelatihan bahasa Inggris agar supaya terjadi interaksi antara guru dan siswa maksimal sehingga dapat mengenal bahasa Inggris dan mencapai hasil belajar yang sesuai dengan tujuan yang dirahapkan. Secara umum, penggunaan media pembelajaran kepada siswa agar lebih mudah fisampaikan, dimengerti bahkan lebih menarik dan lebih menyenangkan bagi para diswa. Keberhasilan dalam proses pembelajaran tergantung pada media pembelajaran dsn juga pada prasarana lain yang dapat mendukung tujuan pembelajaran.

\section{TARGET DAN LUARAN}

Pengabdian Masyarakat ini bertujuan memberikan pelatihan bahasa Inggris melalui media visual sebagai media pembelajaran kedapa siswa SD GMIM 54 Lapangan. Target luaran yang dihasilkan dari kegiatan ini yaitu :

A. Adanya minat dan daya tarik dalam mempelajari bahasa Inggris karena materi dan penyampaiannya menggunakan konsep belajar sambil bermain sehingga kegiatan belajar menjafi aktif dan para siswa tidak bosan dan tidak menjadi satu beban dalam mempelajari materi yang disampaikan.

B. Mengadakan pendekatan yang berorientasi siswa sehingga meningkatkan kepercayaan diri yang dimiliki siswa dalam proses belajar membuat hasil pembelajaran yang dikerjakan para siswa meningkat.

\section{METODE PELAKSANAAN}

Jenis kegiatan yang akan dilakukan berupa pelatihan bahasa Inggris dengan menggunakan media pembelajaran pada siswa-siswa SD GMIM 54 Lapangan. Adapun alur dari metode pelaksanaan kegiatan ini sebagai berikut :

\section{Tahap Persiapan}

A) Identifikadi sasaran kegiatan yang difokuskan pada siswadiswa yang belum mengenal dan terbiasa mempelajari bahasa Inggris dengan menggunakan media pembelajaran bahasa Inggris 
B) Persiapan media pembelajaran yang berhubungan dengan bahan materi, yang sudah dipersiapkan sebaik dan semenarik mungkin.

C) Persiapan siswa dan guru SD GMIM 54 Lapangan yang akan terlibat dalam pelatihan dengan mengedepankan media yang akan digunakan.

2. Tahap Pelaksanaan

A) Pelatihan dan pembuatan media pembelajaran untuk peningkatan ketertarikan siswa dalam mempelajari bahasa Inggris. Dengan adanya penggunaan media pembelajaran diharapkan adanya komunikasi interaktif untuk merangsang para siswa agar dapat aktif mengunkapkan kata-kata dalam bahasa Inggris dengan berani tanpa merasa malu atau terpaksa. Dengan adanya metode pembelajaran menggunakan media gambar tersebut, siswa diharapkan mampu lebih aktif dan mampu melaksanakan ujian, latihan maupun kuis dari guru.

B) Materi yang disampaika : belajar, melalui, gambar, belajar melalui lagu dan melajar melalui bermain.

C) Evaluasi.
3. Tahap Pelaporan

Tahap pelaporan akkhir untuk melaporkan bagaimana hasil yang diperoleh dari pelaksanaan kegiatan di lapangan.

\section{HASIL DAN PEMBAHASAN}

Selama kegiatan pengabdian pada masyarakat ini berlangsung terlihat betapa besar apresiasi para peserta pelatihan yaitu siswa-siswa SD GMIM 54 Lapangan . Hal ini terbukti dengan kehadiran dan partisipasi mereka sepanjang pelatihan berlangsung. Pelatihan bahasa inggris ini adalah pelatihan tingkat komperehensif untuk anak sekolah dasar khususnya kelas 3 dan kelas 4 berdasarkan silabus yang berfokus pada kemampuan berbahasa Inggris Anakanak menikmati pelatihan yang menyenangkan dengan petualangan karakter animasi yang lucu, dan mereka akan terbawa dalam lingkungan berbahasa Inggris yang alami.

Cara belajar bahasa Inggris untuk dewasa memiliki perbedaan dengan anakanak. Karena dunia anak kecil adalah dunia permaianan, maka metode belajar pun harus disesuailkan . metode belajar yang digunakan selama pelatihan ini adalah :

1. Belajar melalui gambar

Materi bahasa Inggris untuk anak biasanya ditekankan pada vocabulary 
yang biasa digunakan sehari-hari. Pengenalan vocab tersebut akan lebih menarik dan mudah dihafal dengan menggunakan gambar yang tentunya menarik.

\section{Belajar dengan lagu}

Metode belajar unuk anak perlu dikombinasikann yaiyu gambar dengan lagu. Dalam menghafal alfabet bahasa Inggris a sampai $\mathrm{z}$ dengan menggunakan lagu dan music, yang didapatkan dari internet. Dengan lagu anak anak terbiasa dengan bahasa inggris

\section{Belajar dan bermain}

Permainan dilakukan terdiri dari dua jenis, pertama permainan fisik, bermain dengan menggunakan tubuh, yaitu Whispering game atau pesan berantai, dengan cara mengumpulkan beberapa anak dan meminta mereka menyampaikan beberapa kata dalam bahasa inggris dengan cara estafet.yang kedua adalah permaianan melalui media,

Materi atau topik pelatihan ini menampilkan contoh-contoh penggunaan kata-kata, frase-frase dan kalimat-kalimat yang sering digunakan dalam keseharian dalam bentuk gambar dan kata. Untuk menghidupkan suasa sana, selama di dalam kelas anak-anak diajarkan bahasa Inggris melalui video cerita, nyanyian dan rima berbahasa Inggris untuk memastikan anak-anak belajar dengan baik, dan menyediakan animasi yang lucu.

Materi yang diberikan meliputi:

\section{Introduction}

Ungkapan-ungkapan yang digunakan untuk memperkenalkan diri ataupun memperkenalkan orang lain.

\section{Greeting}

Ungkapan yang digunakan untuk memberi salam dan merespon, bila bertemu dengan orang lain.

\section{Alphabet}

Menyebutkan abjad a samapai z

4. Numbers

Ungkapan yang berhubungan dengan angka atau bilangan, harga, nomor telephone.

5. The parts of the body Menyebutkan nama-nama bagian tubuh manusia.

\section{Animals}

Menyebutkan nama-nama hewan.

\section{Colours}

Menyebutkan jenis-jenis warna

\section{Verbs}


Menyebutkan kata kerja

\section{Adjectives}

Menyebutkan kata sifat

Dalam pelatihan ini anak anak menikmati pelatihan yang menyenangkan dengan petualangaan karakter animasi yang lucu dan mereka terbawa dalam lingkungan berbahasa Inggris yang alami. Materi yang diajar kan dalam bentuk mendengarkan (listening), berbicara (speaking), membaca (reading) dan menulis (writing).

a. Mendengarkan

Siswa bekerjasama dengan pengajar (yang memberi pelatihan) untuk memahami kosa kata dan mempraktekkan tata bahasa untuk memahami makna dalam sebuah kalimat . siswa diperkenalkan bagaimana mereka mengucapkan alphabet, satu persatu, membangun kosata kata dan memahami ide sederhana.

b. Berbicara

Siswa belajar dan dilatih untuk melafalkan dengan tepat kosakata baru hingga percakapan singkat. Dasar yang tepat sangatlah penting agar mereka bisa melafalkan dengan baik karena pelafan yang sempurna membutuhkan proses yang cukup panjang dan dasar yang besar sangat penting untuk pengembangan kemampuan berbahasa Inggris mereka ke depan.

c. Membaca

Pengajar membimbing kemampuan membaca siswsa yang berfokus pada kata ejaan dan pengenalan kata pada level awal. Dengan mengembangkan kemampuan membaca di kelas melalui bunyi bahasa Inggris yang akrab didengar .

d. Menulis

Siswa belajar meniru bentuk dasar huruf, kemudian menyalin kata dan kalimat, dan pada akhirnya mampu menulis cerita pendek mereka sendiri.

Dalam kegiatan ini semua materi atau topik yang diberikan, digandakan untuk mempermudah dan memperlancar kegiatan pelatihan ini sehingga pencapaian hasil menjadi maksimal sesuai yang diinginkan. 
KESIMPULAN DAN SARAN

\section{Kesimpulan}

Pelaksanaan kegiatan pelatihan

bahasa Inggris bagi siswa-siswa SD GMIM

54 Lapangan telah memberikan manfaat yang besar bagi setiap peserta. Melalui pelatihan ini para peserta telah memiliki cukup kosakata dalam bahasa Inggris, anak anak yang sejak dini telah diajarkan bahasa Inggris, pelajaran tersebut tersimpan dalam memori dan menjadi fondasi dari anak tersebut sehingga mereka tidak kesulitan lagi belajar baahasa Inggris pada saat di sekolah lanjutan maupun pada perguruan tinggi, karena mereka sudah memiliki basic.

\section{Saran}

Namun disadari pelatihan ini belum menjangkau semua kebutuhan ketrampilan berbahasa yang dibutuhkan dalam penggunaan bahasa Inggris sebagai bahasa pengantar. Oleh karena itu diharapkan agar kegiatan seperti ini kembali dapat dilaksanakan untuk meningkatkan kemampuan ketrampilan berbahasa para siswa-siswa SD setelah memperoleh ketrampilan dasar ini.

\section{KEPUSTAKAAN}

Cahyono, Bambang Y. The Teaching of English Language Skills and English Language Components, Malang: State University of Malang Press.2010

Ferrer-Hanreddy, Jami \& Whalley, Elizabeth. A Listening/Speaking Skills Book: With Learning Strategies and Language Functions, Singapore: McGraw-Hill Companies, Inc. 1996

Silberman, Mel. Active Learning: 101 Strategi Pembelajaran Aktif, Yogyakarta: Pustaka Insan Madani. 2009.

Tillit Bruce \& Bruder Mary N. Speaking Naturally - Communication Skills In American English, Cambridge : Cambrige University Press. 
Jurnal ABDIMAS, Vol. 12, No. 2, Agustus 2019

ISSN: 1979-0953 | e-ISSN: 2598-6066 